\title{
EFFECT OF DIFFERENT CUTTING INTERVALS ON THE FORAGE YIELD AND SOME SILAGE QUALITY CHARACTERISTICS OF GIANT KING GRASS (Pennisetum hybridum) UNDER MEDITERRANEAN CLIMATIC CONDITIONS
}

\author{
Hakan GEREN ${ }^{1}$, Yasar Tuncer KAVUT ${ }^{1}$, Hayrullah Bora UNLU ${ }^{2}$ \\ ${ }^{1}$ Ege University, Faculty of Agriculture, Dept. of Field Crops, Izmir, TURKEY \\ ${ }^{2}$ Ege University, Faculty of Agriculture, Dept. of Anim. Nutr. \& Feed Sci., Izmir, TURKEY \\ Corresponding author: hakan.geren@ege.edu.tr
}

Received: 09.08.2019

\begin{abstract}
This study was conducted in Bornova experimental fields of Department of Field Crops, Faculty of Agriculture, University of Ege, Turkey during 2015 and 2016, in order to determine the effect of six different cutting intervals (30-, 60-, 90-, 120-, 150- and 180- days) on the forage yield and some quality properties of giant king grass (Pennisetum hybridum). The experimental design was in complete randomized blocks, with three replications. 6 years old, Paraíso cultivar of giant king grass (GKG) was used as crop material. Some characteristics were measured such as dry matter (DM) yield, concentrations of crude protein (CP), NDF and ADF. Results indicated that there were significant effects of cutting intervals on the yields and some silage quality characteristics of GKG, and, metabolisable energy and relative forage values decreased as inter-cutting interval increased. It was recommended that the production of GKG using 60- day intervals were the most successful cutting frequency regarding the forage yield and silage quality to the regions with Mediterranean-type climates under irrigation.
\end{abstract}

Keywords: Cutting interval, DM yield, giant king grass, Pennisetum hybridum, silage quality

\section{INTRODUCTION}

In most ruminant production systems, livestock derive between 40 and $90 \%$ of their feed requirements from forages. Haymaking and ensiling are the only options available to farmers wanting to conserve forage on a large scale. Ensiling offers many advantages over haymaking: large quantities of forage can be conserved in a short time, forage conservation is less weather dependent and silage is well suited to mechanization (Charmley, 2001).

Corn (Zea mays) silage is a major forage source for dairy cows in Turkey because of its relatively constant nutritive value, high yield, and high net energy for lactation requirements compared with other forage crops (Carpici et al., 2010). Corn forage yield for silage and its quality are influenced by many interacting environmental, cultural, production costs (hybrid seed, irrigation, etc.) and genetic factors. Therefore, the producers are trying to reduce production costs by better use of grazing and alternative crops for silage making. Giant king grass (Pennisetum hybridum) cultivation under field conditions in Mediterranean environment may be one of those alternatives to produce large amount of high quality roughage (feed) instead of corn (Geren et al., 2014; Geren and Kavut, 2015).
GKG as an interspecific hybrid (6n) has been formed between Napier grass (Pennisetum purpureum) $(2 \mathrm{n}=4 \mathrm{x}=28$ chromosomes) and pearl millet (Pennisetum glaucum) ( $2 n=2 x=14$ chromosomes) the resulting hybrid is sterile due to the triploid condition $(2 n=3 x=21$ chromosomes $)$ and restored by chromosome duplication with the use of colchicine (Hanna et al., 1984). GKG also known as 'Maralfalfa' is a perennial forage grass with a high growth rate, high productivity and good nutritive value and it is mostly used for 'cut and carry' system over the tropical and sub-tropical areas of the world (Wadi et al., 2004). GKG is very palatable to animals at the early leafy stage, but not much liked after stem development.

Forage crops differ considerably in terms of their ability to recover from defoliation which is strongly influenced by management practices, particularly the frequency, intensity and timing of cutting. Responses of forage plants to cutting practice can be explained by two guiding principles (Bazzaz et al., 1987). The first factor is that cutting practice disturbs the carbohydrate supply for plant growth by removing photosynthetic tissue. The second factor is that plant growth processes generally operate to maintain plants in a dynamic equilibrium with their environment so that optimum use is made of all resources for growth and reproduction. The relationship between herbage production and the frequency 
and intensity of cutting has received widespread attention with regard to DM yield and quality of forage crops.

Cutting interval or frequency of between cuts after crop establishment is the common agronomic factors, which affect growth characteristics, DM yield and nutritional quality of perennial forage grass like Pennisetum hybridum, $P$. purpureum, Miscanthus $s p$. etc. (Lounglawan et al., 2014). The harvesting frequency may vary by climatic conditions but should coincide with the timing of high forage quality and the duration between two cuttings depending on the time needed by the plant to regrow (Wadi et al., 2004). Generally, it has been found that the extending cutting intervals, the higher DM yield, the higher to proportion of stem and the higher crude fiber concentration. Digestibility, CP concentration and proportion of green leaf blade drop correspondingly (Campos et al., 2002).

As it well known, herbage production in the sward is divided into two components; the number of tillers per unit area and the yield per individual tiller. Obviously, this is also influenced by tiller dynamics i.e. the balance between the production of new tillers and death of established tillers. Recovery from defoliation can be determined by many aspects such as shoot apex survival, leaf area, non-structural carbohydrate content and tiller potential. However, it also depends, not only on the genetic capacity of the plant and the characteristics of cutting practice, but also on the plant's abiotic environment e.g. light, water, nutrients (Geren, 2014a; Geren and Kavut, 2015; Nazli et al., 2018). Many researchers have suggested that cutting practices must be adjustable to the season and climatic conditions of the year (Geren et al., 2014; Nazli et al., 2018).

The regrowth after cutting practices is another important physiological processes and it determines the herbage quality. Wijitphan et al. (2009) reported that DM yield of Napier grass was increased by extending the intervals of cutting from 4- to 7- weeks. In another study, Mohammad et al. (1988) obtained highest DM yield on $3.3 \mathrm{t} \mathrm{ha}^{-1}$ from Napier grass clipped at 8- week interval. However, before recommending giant king grass as forage crop to farmers, it is essential to understand and determine the relationships between growth characteristics, DM yield, nutritional quality and management practices such as frequency of defoliation to maintain growth of GKG. The objective of this research was to evaluate the influence of different cutting intervals on the DM yield, some yield and silage quality components of GKG under irrigated conditions of Mediterranean climate.

\section{MATERIALS AND METHODS}

\section{Location of Experiment}

The experiment was carried out during two growing seasons (2015 and 2016) at Bornova experimental fields $\left(38^{\circ} 27.236 \mathrm{~N}, 27^{\circ} 13.576 \mathrm{E}\right)$ of Agricultural Faculty of Ege University, Izmir, Turkey, at about $20 \mathrm{~m}$ above sea level with typical Mediterranean climate characteristics (Table 1). The soil was a silty-clay loam $(30.6 \%$ clay, $36.7 \%$ silt, and $32.7 \%$ sand) with $\mathrm{pH} 7.32$, organic matter $1.16 \%$, salt $0.074 \%, 0.123 \%$ total $\mathrm{N}$, available phosphorus (1.4 ppm) and available potassium (350 $\mathrm{ppm})$.

Table 1. Some meteorological parameters of experimental area at Bornova in 2015 and 2016

\begin{tabular}{|c|c|c|c|c|c|c|}
\hline & \multicolumn{3}{|c|}{$\begin{array}{c}\text { Average } \\
\text { temperature } \\
\left({ }^{\circ} \mathrm{C}\right) \\
\end{array}$} & \multicolumn{3}{|c|}{$\begin{array}{c}\text { Total } \\
\text { precipitation } \\
(\mathbf{m m})\end{array}$} \\
\hline & 2015 & 2016 & LYA & 2015 & 2016 & LYA \\
\hline January & 8.9 & 8.8 & 9.0 & 125.1 & 232.9 & 112.2 \\
\hline February & 9.5 & 13.8 & 9.2 & 101.9 & 84.9 & 99.7 \\
\hline March & 11.7 & 13.7 & 11.8 & 75.6 & 122.0 & 82.9 \\
\hline April & 15.9 & 18.9 & 16.1 & 46.4 & 28.4 & 46.4 \\
\hline May & 20.8 & 20.7 & 21.0 & 30.9 & 37.1 & 25.4 \\
\hline June & 25.6 & 27.5 & 26.0 & 9.8 & 2.8 & 7.5 \\
\hline July & 28.0 & 29.3 & 28.3 & 1.8 & - & 2.1 \\
\hline August & 27.7 & 28.9 & 27.9 & 2.6 & 0.4 & 1.7 \\
\hline September & 23.7 & 24.7 & 23.9 & 15.0 & 8.6 & 19.9 \\
\hline October & 18.8 & 19.4 & 19.1 & 45.3 & 0.5 & 43.2 \\
\hline November & 14.0 & 14.2 & 13.8 & 94.8 & 123.8 & 109.7 \\
\hline December & 10.6 & 7.1 & 10.5 & 141.1 & 20.2 & 137.9 \\
\hline $\mathbf{X}-\Sigma$ & 17.9 & 18.9 & 18.1 & 690.3 & 661.6 & 688.6 \\
\hline
\end{tabular}

LYA: Long years average, $\mathbf{X}$ : Mean, $\Sigma$ : Total

\section{Field applications and experimental design}

6 years old "Paraíso" cultivar of GKG was used as crop material. The experiment was carried out with a randomized complete block design with three replications. Each plot was consisted of four rows with $70 \mathrm{~cm}$ among the rows and five-meter length $\left(14 \mathrm{~m}^{2}\right)$. Six different cutting frequencies (30-, 60-, 90-, 120-, 150- and 180- days intervals) were tested. Cutting intervals and number of harvests are presented schematically in Figure 1. 


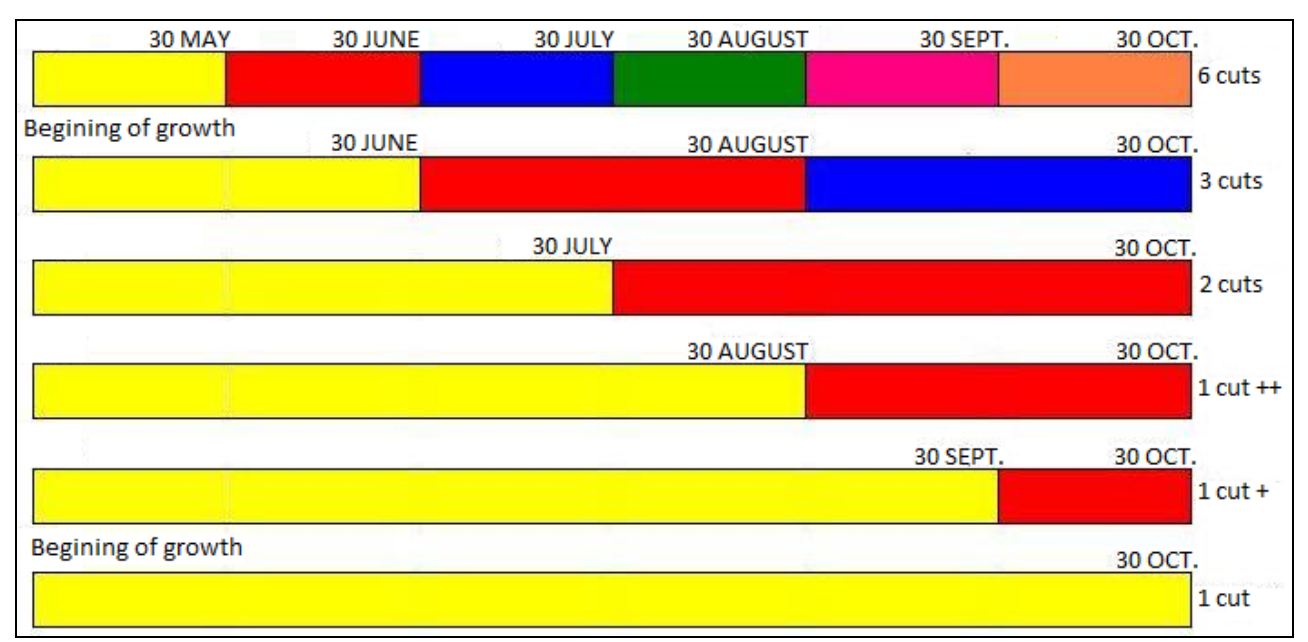

Figure 1. Number of harvests and cutting intervals tested in the experiment.

The recommended dose of $210 \mathrm{~kg} \mathrm{~N} \mathrm{ha}^{-1}$ was applied for all plots in three equal doses in every growing season (Mohammad et al., 1988). All plots were fertilised using 80 $\mathrm{kg} \mathrm{ha}^{-1} \mathrm{P}_{2} \mathrm{O}_{5}$ and $80 \mathrm{~kg} \mathrm{ha}^{-1} \mathrm{~K}_{2} \mathrm{O} .1 / 3$ of $\mathrm{N}$ and full dose of $\mathrm{P}$ and $\mathrm{K}$ fertilization was applied by helping of drip irrigation system at the beginning of April. The other 1/3 doses of $\mathrm{N}$ were applied $30^{\text {th }}$ June and $30^{\text {th }}$ August, in both experimental years, respectively. Drip irrigation system was installed on the field during growing seasons. No weed control was performed during growing years, except the plots cut every 30- day (hand hoeing was done). No evident crop diseases or insects were detected. Harvest was started at $30^{\text {th }}$ of May, and continued at the end of October in both experimental years.

\section{Measurements, silage making and chemical analysis}

In each plot, plant height was measured from in the mid two rows and area of 1-3 m (30 plants) at the day of cutting. Tiller density was also determined by counting the plant in the same area in each plot at the same day of cutting. Forage on a central area of three $\mathrm{m}^{2}$ in each plot was cut at $15 \mathrm{~cm}$ above ground level and fresh weight recorded. Harvested fresh forage $(2 \mathrm{~kg})$ was dried to a constant weight at $105^{\circ} \mathrm{C}$ during $24 \mathrm{~h}$ for calculating dry matter.

In each plot, about $5 \mathrm{~kg}$ of fresh whole crop material were wilted according to 'Grab Test' (Comberg, 1974) prior to ensiling. The final DM content was between 28$30 \%$. The wilted herbages were then chopped, using a static precision-chop forage harvester to give a chop length of 5$10 \mathrm{~mm} .2 \mathrm{~kg}$ chopped samples were vacuum-packed into polythene bags (Johnson et al., 2005) with addition of $0.5 \%$ salt. No inoculant was applied to any combination. The vacuum bag silos were kept in storage without light for 45 days for anaerobic fermentation.

$\mathrm{pH}$ value of matured silage samples was also determined (Alcicek and Ozkan, 1996). Matured silage samples of each component were dried at $65^{\circ} \mathrm{C}$ for $48 \mathrm{~h}$. The dried samples were reassembled and ground in a mill passed through a $1 \mathrm{~mm}$ screen. Crude protein $(\mathrm{CP})$, crude fibre $(\mathrm{CF})$, ether extractable fat $(\mathrm{EEF})$ and total ash of forages were determined using standard techniques as prescribed by AOAC (1991). Metabolisable energy (ME, $\left.\mathrm{kcal} \cdot \mathrm{kg}^{-1}\right)$ was calculated by the formula, $\mathrm{ME}=3260+$ $\left(0.455 \times \mathrm{CP}_{\%}\right)+\left(3.517 \times \mathrm{EEF}_{\%}\right)-\left(4.037 \times \mathrm{CF}_{\%}\right)(\mathrm{TSE}$, 2004). The neutral detergent fibre (NDF) and acid detergent fibre (ADF) concentrations were analysed by the sequential detergent analysis method (Goering and VanSoest, 1970).

\section{Statistical analysis}

All data were statistically analyzed using analysis of variance (ANOVA) with the Statistical Analysis System (SAS, 1998). In each cutting frequency, the sum of DM yield and the average of the other characteristics were evaluated. Probabilities equal to or less than 0.05 were considered significant. If ANOVA indicated differences between treatment means a LSD test was performed to separate them (Stell et al., 1997).

\section{RESULTS AND DISCUSSION}

The experimental area (Bornova) is characterized by a typical Mediterranean climate with hot \& dry summers and cool \& humid winters that generally prevailed during both experimental years (2015 and 2016) and long term average. However, as illustrated in Table 1, monthly total precipitation was substantially variable between 2015 and 2016. In both years, air temperature was similar to each other and long year's average. Field studies were started on 6 years old giant king grass in April by increasing temperature and then satisfactory moisture levels supported by drip irrigation, therefore, stands were excellent. No winter injury on the crops was detected during winter period of the experimental years. We obtained " $6,3,2$, $1+(60$ - day growth), 1+(30- day growth), 1 " number of cuts for intervals 30-, 60-, 90-, 120-, 150- and 180- days in each year in our study, respectively. There were significant $(\mathrm{P}<0.05)$ differences among the cutting interval (frequency) on all growth, yield and chemical characteristics of giant king grass (Table 2). 
Table 2. Means of cutting intervals on the yield and some silage quality components of GKG.

\begin{tabular}{|c|c|c|c|c|c|c|c|c|}
\hline \multirow[b]{2}{*}{ Cutting interval } & 2015 & 2016 & 2015 & 2016 & 2015 & 2016 & 2015 & 2016 \\
\hline & \multicolumn{2}{|c|}{$\begin{array}{l}\text { Plant height } \\
\text { (cm) }\end{array}$} & \multicolumn{2}{|c|}{$\begin{array}{c}\text { Tiller number } \\
\left(\mathbf{m}^{-1}\right)\end{array}$} & \multicolumn{2}{|c|}{$\begin{array}{c}\text { Dry matter yield } \\
\left(\mathrm{t} \cdot \mathrm{ha}^{-1}\right)\end{array}$} & \multicolumn{2}{|c|}{ Silage pH } \\
\hline 30- day & 143.3 & 142.7 & 141.3 & 121.8 & 19.75 & 16.28 & 4.41 & 4.33 \\
\hline 60- day & 263.0 & 269.3 & 62.7 & 66.3 & 42.55 & 42.03 & 4.16 & 4.13 \\
\hline 90- day & 334.7 & 338.0 & 82.0 & 81.7 & 39.31 & 40.76 & 3.83 & 3.80 \\
\hline 120- day & 300.8 & 304.0 & 69.3 & 65.5 & 38.92 & 40.34 & 4.00 & 3.97 \\
\hline 150- day & 238.3 & 271.3 & 111.0 & 106.8 & 44.25 & 43.40 & 4.11 & 4.09 \\
\hline 180- day & 428.3 & 426.7 & 161.3 & 157.7 & 51.18 & 51.51 & 3.73 & 3.67 \\
\hline \multirow{3}{*}{ LSD (.05) } & 284.8 & 292.0 & 104.6 & 100.0 & 39.33 & 39.05 & 4.04 & 4.00 \\
\hline & \multicolumn{2}{|c|}{$\begin{array}{l}\text { Y:ns CI:12.7 } \\
\text { YxCI: ns }\end{array}$} & \multicolumn{2}{|c|}{$\begin{array}{c}\text { Y:4.2 CI:7.2 } \\
\text { YxCI: ns }\end{array}$} & \multicolumn{2}{|c|}{$\begin{array}{c}\text { Y:ns CI:1.91 } \\
\text { YxCI :ns }\end{array}$} & \multicolumn{2}{|c|}{$\begin{array}{c}\text { Y:0.04 CI:0.06 } \\
\text { YxCI: ns }\end{array}$} \\
\hline & \multicolumn{2}{|c|}{$\begin{array}{c}\text { CP content } \\
(\%)\end{array}$} & \multicolumn{2}{|c|}{$\begin{array}{c}\text { Metabolisable energy } \\
\left(\mathrm{kcal} \cdot \mathrm{kg}^{-1}\right)\end{array}$} & \multicolumn{2}{|c|}{$\begin{array}{c}\text { NDF } \\
(\%)\end{array}$} & \multicolumn{2}{|c|}{$\begin{array}{c}\text { ADF } \\
(\%)\end{array}$} \\
\hline 30- day & 11.8 & 12.0 & 1860 & 2030 & 54.6 & 53.6 & 37.5 & 36.7 \\
\hline 60- day & 8.1 & 8.6 & 1627 & 1973 & 63.6 & 64.0 & 40.8 & 40.5 \\
\hline 90- day & 6.1 & 6.2 & 1401 & 1771 & 64.6 & 68.4 & 44.6 & 41.7 \\
\hline 120- day & 8.0 & 8.0 & 1394 & 1600 & 65.1 & 64.7 & 42.5 & 40.9 \\
\hline 150- day & 8.6 & 9.0 & 1545 & 1904 & 63.1 & 60.5 & 40.8 & 40.6 \\
\hline 180- day & 4.5 & 5.0 & 1267 & 1353 & 73.9 & 72.1 & 46.7 & 46.4 \\
\hline Mean & 7.8 & 8.1 & 1516 & 1772 & 64.1 & 63.9 & 42.2 & 41.1 \\
\hline $\operatorname{LSD}(.05)$ & $\begin{array}{r}\text { Y:ns } \\
\text { Yx }\end{array}$ & $\begin{array}{l}\mathrm{I}: 0.3 \\
0.5\end{array}$ & & & $\begin{array}{r}Y: n \\
Y\end{array}$ & $\begin{array}{l}{[: 0.7} \\
.9\end{array}$ & $\begin{array}{r}\mathrm{Y}: 0 . \\
\mathrm{Yx}\end{array}$ & $\begin{array}{l}\mathrm{I}: 0.7 \\
1.0\end{array}$ \\
\hline
\end{tabular}

Y: year, CI: cutting interval, YxCI: interaction, ns: not significant.

\section{Plant height}

ANOVA results indicated that the plant height of GKG was significantly affected by cutting intervals. In both experimental years, once harvest (180- day) during season (2015: $428.3 \mathrm{~cm}, 2016: 426.7 \mathrm{~cm}$ ) had the longest plant, whereas 6 times harvest (30- day cutting intervals) during growing period had the shortest $(2015: 143.3 \mathrm{~cm}, 2016$ : $142.7 \mathrm{~cm}$ ) (Table 2), respectively. Year effect was not significant on the plant height.

In our experiment, as the inter-cutting interval increased (from 30- to 180- days), plant height at harvest increased significantly, especially in the first cut of each cutting regime (not seen in Table 2) in both year due to the plant height was related to the age of plant. Table 2 indicated that plant height increased as the cutting interval decreased (from 30- to 90- days) and then gradually decreased till 150- days, but later increased for 180- days [once cut per growing season]. The main reason of this decline on plant height for 120- or 150- days cutting interval was their limited regrowth (the reduction in the average of the recorded heights). Development periods of regrowth for 120 - or 150- day interval were only 60- and 30- days until at the end of October, respectively. Therefore, their average plant heights were limited compare to once cut (180- day) per season. Thus, similar results were obtained from the studies conducted in different geographical regions and it was indicated that the plant heights were different in perennial tall forage grass varieties under different cutting intervals or plant age (Rengsirikul et al., 2011; Magalhães et al., 2004). Wadi et al. (2004) informed that plant height was higher in the plants cut at a 90- day interval than at a 60 - day interval. Another study with $P$. purpureum by Magalhães et al. (2004) informed that with the decreasing cutting frequency from 28-, 35-, 42-, 56- to 84- days, plant height increased from $60.1,71.7,92.1,131.0$ to $173.1 \mathrm{~cm}$, respectively.

Concerning plant height, giant king grass performed growth rates of about $3 \mathrm{~cm}$ per day already from its emergence (3-4 April) until at the end of June, when it reached $260 \mathrm{~cm}$ in height under the experimental ecology. After June, the crop continued growing but at relatively lowers rates $\left(1.5-2.5 \mathrm{~cm} \mathrm{day}^{-1}\right)$ to reach finally over $425 \mathrm{~cm}$ in height by the end of October. These results generally exhibiting those plants cut every 60- or 90- days by reaching 265 or $335 \mathrm{~cm}$ height, that the crop is very well adapted to experimental area.

\section{Number of tiller}

There were statistically significant differences among the cutting intervals regarding average number of tiller per meter (Table 2). The oldest crops being 180- days interval had the highest average number of tiller (2015: 161.3 and 2016: 157.7 tiller $\mathrm{m}^{-1}$ ), whereas cutting practice with 60day interval was the lowest (2015: 62.7 and 2016: 66.3 tiller $\mathrm{m}^{-1}$ ), but there was no significant difference between 60and 120- day interval (2015: 69.3 and 2016: 65.5 tiller $\mathrm{m}^{-1}$ ). Year effect was also significant and average number of tiller of first year $\left(104.6\right.$ tiller $\left.\mathrm{m}^{-1}\right)$ was slightly higher than second year (100.0 tiller $\left.\mathrm{m}^{-1}\right)$.

Tiller density is another factor that can impinge on forage productivity. In the present study, the effect of cutting interval on average number of tillers of GKG was considerably variable. Crops harvested every 30- days produced many (over 240 tiller $\mathrm{m}^{-1}$ ) fine-stemmed (diameter 8-10 $\mathrm{mm}$ ) tillers until the end of June (not seen in Table 2), to gradually decrease thereafter to values around 
50 tillers per meter in both years. Rengsirikul et al. (2011) stated that peak number of tiller (132 tiller $\left.\mathrm{m}^{-1}\right)$ occurred with 1-month inter-cutting interval, while a 6- month interval produced with 38 tiller $\mathrm{m}^{-1}$ on P.purpureum. Mushtaque et al. (2010) informed that tiller per plant in tropical grasses increased significantly from the youngest plants to the older ones. Although the crops were 6 years old in the study, harsh and destructive effect was determined on average number of tillers with intervals of 30- days between cuts in the second year. In addition to that, duration of emergence tiller from soil in spring was delayed by about 10 days in the second year. Whereas crops harvested every 60- or 90- day formed more stable and relatively thick stem (diameter $[\phi] 60-$ day: $15-18 \mathrm{~mm}$ and 90- day: 18-22 mm) tillers with full and green leaves. On contrary, the first harvest of 120- and 150- day intervals had thick stemmed $(\phi: 20-25 \mathrm{~mm})$ tillers but $35-40 \%$ lost green leaves. Especially, regrowth of 150- day treatment showed a surprising increase in tiller number per meter (from 60 to 160 tillers) (not seen in Table 2). Wadi et al. (2004) stated that regrow tiller number was higher in the plants cut at a 60- day than at a 90-day interval. Chong-jian et al. (2011) pointed out that the numbers of tillers, effectual stems and nodes of hybrid giant napier have the most important contribution to its fresh yield.

Plants harvested once per year (180- day) produced longest and thick stemmed $(\phi: 24-27 \mathrm{~mm})$ tillers with dead leaf of $60 \%$. In other words, fresh leaf rate on the crop declined as inter-cutting interval increased with a corresponding increase in dead leaf material up to the 6month interval. On this basis, when GKG is harvested as livestock feed; the recommended inter-cutting interval is no more than 90- days, as feed quality declines by decreasing leafiness of the sward.

The results obtained in this study also showed that the effects of a long interval between cuts increased growth rate mainly by producing a higher proportion of stem (not seen in Table 2) rather than leaf. In other words, frequent cutting encouraged a higher proportion of leaf than infrequent cutting as shown by the leaf:stem ratios. Bazzaz et al. (1987) noted that this is partly because defoliation stimulates branching and leaf differentiation, and partly because the sward is maintained in a more juvenile condition. Our findings are in accordance with those researcher's results.

\section{Dry matter yield}

The DM yield was not affected by interaction. There were statistically significant differences among cutting intervals regarding DM yield per hectare (Table 2). The highest average DM yield of GKG was obtained from 180day interval (2015: 51.18 and 2016: $51.51 \mathrm{t} \cdot \mathrm{ha}^{-1}$ ), whereas the lowest average yield obtained from 30- days interval (2015: 19.75 and 2016: $16.28 \mathrm{t} \cdot \mathrm{ha}^{-1}$ ). However, there was no significant difference between 150- and 60- day intervals in both years. Year effect was not significant on DM yield.

In the present study, as inter-cutting interval increased from 30- to 60- days, total DM yield of GKG increased, and then decreased to the 120- day interval, while peak DM yields were reached at the 180- day inter-cutting interval. Although, dead leaf material in the sword increased after 120-day interval in the first cut of each cutting regime in both year, while it was limited 90- day interval, there was no dead material in 30- or 60- day interval. Loss of dead leaf is not determined in our study, but variable quantities of dead leaf were observed on the crop, and this has possibly contributed to increased variation in measured DM yield. This suggests that for practical purposes harvest ages above 60 days may be too long under the conditions of the experiments. On the other side, the rates of regrowth on the total DM yield for 120- and 150- day cutting intervals were approximately $7 \%$ and $3 \%$, respectively.

DM yield variation in perennial warm season grasses has been attributed to many factors such as climatic conditions, soil water availability, nutrients availability, plant density, harvest time and method, etc. (Campos et al., 2002; Wadi et al., 2004; Singh et al., 2013). Some cutting experiments with GKG also revealed in tropic countries that the choice of cutting interval or frequency is crucial to their performance and were found to be the main factor affecting growth, yield and persistence of swards. In addition to that, many researcher emphasized that DM yield in tropical grasses was positively correlated with plant height, mean tiller weight, crop growth rate and cutting management (Tegami Neto and Mello, 2007; Zewdu, 2008; Wijitphan et al., 2009). Tegami Neto and Mello (2007) reported that there was a significant difference in DM yield between 30 and 60- day cutting intervals in P. hybridum in Brazil, and DM yield was higher in the plants at a 60- day $\left(78.26 \mathrm{t} \mathrm{ha}^{-1}\right)$ than at a 30-day interval (43.36 $\left.\mathrm{t} \mathrm{ha}^{-1}\right)$. Magalhães et al. (2004) informed that DM yield of $P$. purpureum in Brazil significantly increased in line with plant age at cutting, with age at cutting of 84- days yielding the best results $(18.93 \mathrm{t}$ $\left.\mathrm{ha}^{-1}\right)$, followed by 56- $\left(9.48 \mathrm{tha}^{-1}\right)$, and 42- days (5.02 $\mathrm{t} \mathrm{ha}$ $\left.{ }^{1}\right)$. Another experiment in Japan by Wadi et al. (2004) pointed out that annual DM yield of Pennisetum species was higher in the plants at a 90- day $\left(22.6 \mathrm{t} \mathrm{ha}^{-1}\right)$ than at a 60- day interval $\left(14.8 \mathrm{tha}^{-1}\right)$. Our findings are in accordance with those researcher's results.

\section{Silage $\mathrm{pH}$}

ANOVA results showed that cutting interval had a significant effect on the silage $\mathrm{pH}$ of GKG silage in the study (Table 2). The values of silage $\mathrm{pH}$ ranged from 3.67 to 4.33 depending on the plant age and years. The silage $\mathrm{pH}$ decreased as the frequency of cutting decreased from 30- to 90- day, however after 90- day, $\mathrm{pH}$ increased to 150 - day, and after decreased most probably due to the regrowth period for additional cutting in our study. Year effect was also significant on $\mathrm{pH}$ values and average $\mathrm{pH}$ value of first year (4.04) was higher than second year (4.00).

As it well known, the most important physicochemical parameter for the evaluation of silage quality is a $\mathrm{pH}$ below four, (Comberg, 1974) which was observed for some silage tested. Other indicators (concentrations of lactic and acetic acids, not seen in Table 2) were the characteristic of good silage conservation whatever the treatments were. Many research (Bernardino et al., 2005; Ruviaro et al., 2008; 
Ferrari Junior et al., 2009; Shen et al., 2012) reports revealed that plant age depending on accumulation of water-soluble sugar are the major factors that affect silage fermentation of warm season forage grasses. Some experiments conducted Mediterranean climatic condition on GKG indicated that silage $\mathrm{pH}$ values of GKG depend on silage additive and plant density. For instance, silage $\mathrm{pH}$ values of $P$. hybridum cut once during growing season have been reported as between 3.7 to 4.3 (Geren, 2014b; Geren et al., 2014). Woodard et al. (1991) informed that mean $\mathrm{pH}$ values of $P$. purpureum silages ranged from 3.8 to 4.0 made from plants harvested at the different intervals, and the ease with which $P$. purpureum was preserved as silage was attributed to adequate levels of water-soluble carbohydrate concentrations and inherently low buffering capacities in standing forages.

\section{Crude protein content of silage}

$\mathrm{CP}$ content of silage of GKG was affected by interaction (Table 2). The highest average CP content (12.0\%) recorded at 30- day interval in 2016, whereas the lowest CP content was $4.5 \%$ at 180 - day interval in 2015. Mean CP content was significantly higher in second year $(8.1 \%)$ than the first years $(7.8 \%)$

Findings indicated that cutting practices (interval) affected CP content of GKG significantly. However, CP content did decline from $11.8-12.0 \%$ to $4.5 \%-5.0$ as intercutting interval increased from 30- to 180- days in both years, respectively. It is widely reported that $\mathrm{CP}$ content decreases as cutting interval increases (Carvalho et al. 2000; Tessema et al., 2010). For example, Carvalho et al. (2000) informed that the CP content of $P$. purpureum decreased as the plant maturity progressed (28-, 35-, 42-, 49-, 56-, 63- days), however they were always above $7 \%$ in Brazil. This is related to a decrease in $\mathrm{N}$ concentration as plant maturation. In the present study, average $\mathrm{CP}$ contents of 120- or 150- days were higher than 60- or 90 days. The reason of mini increase in 120- or 150- days were their second regrowth which relatively high $\mathrm{CP}$ content. The current results are in agreement with Rengsirikul et al. (2011) who found that cutting $P$. purpureum grass 1- month interval obtained the average of $\mathrm{CP} 12.5 \%$, when the cutting interval extended to 2-, 3- or 6- months, the average of CP decreased to $11.3,9.4$ and $8.1 \%$, respectively. In addition, Tegami Neto and Mello (2007) who found that range of the CP content of GKG were 13.0-11.5\% and 10.211.9, when cut 30 - or 60- days of cutting interval in Ituverava-Brazil, respectively. Our findings are also in accordance with the results of researchers above.

Although highest DM yield were obtained when the GKG was cut 180- days, the forage was of poor quality as indicated by its low $\mathrm{CP}$ and mineral content, and high lignin content. On the other hand, when the GKG was cut every 30 days the quality was excellent but DM yields were lower, it was often difficult to maintain a good stand, more frequent weeding was necessary, and cost of harvesting was higher. Other researchers (Campos et al., 2002; Wadi et al., 2004) have mentioned that yields of DM in tropic grasses are associated with infrequent cutting but $\mathrm{CP}$ content not.
For this reason, a point where the intersection of quality with a satisfactory yield should be proposed. Generally, a 60- day harvest interval would seem to be a reasonable compromise between high yields and ease of management in the present study, however with a somewhat shorter interval can be used during growing season.

\section{Metabolisable energy}

ME value of silage of the grass was affected by interaction (Table 2). The highest average ME value (2030 $\mathrm{kcal} \mathrm{kg}^{-1}$ ) recorded at a 30- day intervals in 2016, whereas the lowest ME was $1267 \mathrm{kcal} \mathrm{kg}^{-1}$ at 180- day in 2015 . Mean ME value was significantly higher in second year $\left(1772 \mathrm{kcal} \mathrm{kg}^{-1}\right)$ than the first years $\left(1516 \mathrm{kcal} \mathrm{kg}^{-1}\right)$.

Metabolisable energy refers to the feed energy available for intermediary metabolism, a considerable fraction of which is retained in the animal's tissues for maintenance and growth or leaves the animal in form of products (Mohammad et al., 1988; Mbuthia, 2003). Knowledge of $\mathrm{ME}$ value of feedstuffs allows more accurate formulation of rations for animals. The $\mathrm{ME}$ of forage is positively correlated with the $\mathrm{CP}$ and ether extractable fat content, but not crude fiber. In the present study, forage quality of GKG has been changed at different growth stages, so harvesting stage in other word plant age is an important factor on ME content. The ME calculated from regression equations, decreased as inter-cutting interval increased from 30- to 180- days in both years, respectively. However, ME increased at 150- day cutting interval compared to 120 - or 90- days, and after decreased most probably due to the regrowth period for additional cutting in both years in the study. Mbuthia (2003) ensiled P. purpureum harvested at two stages of growth (8- or 12- weeks) in Kenya, and, the results evidenced that cutting interval responded strongly to $\mathrm{ME}$ content and energy ranged 7.1 and $6.9 \mathrm{MJ} \mathrm{kg}^{-1}$. From the results obtained in the present study, it would be more advantageous to the farmer to make silage at 60- day of age due to the higher DM yields, since neither the silage quality nor the energy content are compromised.

\section{$N D F$ and $A D F$ content}

The analysis of variance indicated that cell wall components (NDF and ADF) were affected by year-cutting interval interaction (Table 2). The favourable average NDF content (53.6\%) was recorded at 30- day cutting interval in the second year, whereas the highest content $(73.9 \%)$ was in the first year at 180- day. Year effect was not significant on NDF. Similar trend was determined in ADF content as the growth period increased. The maximum ADF content (46.7\%) was measured in 2015 at 30 - day cutting interval, while minimum $\operatorname{ADF}(36.7 \%)$ was measured at 180 - day in 2016. Year effect was also significant and average ADF content of first year $(42.1 \%)$ was higher than the following year $(41.1 \%)$.

NDF and ADF contents of GKG silage increased with delaying harvesting interval as expected because of the progressing maturation of the grass. The cell wall components reflect the potential intake of forage (Mbuthia, 2003). These components tended to increase with 
increasing cutting interval. At large, silage made at 60- day cutting interval performed better than the other cutting practices with regard to NDF and ADF contents in the study. Although silage made at 120 - or 150 - days cutting interval seems to be the same group at 60-days with regard to cell wall components, the reason was that they had second re-growths, which were relatively fresh.

Silage made at once cut during season had greater NDF and $\mathrm{ADF}$ concentrations than the other cutting treatments. Many research workers (Geren et al., 2014; Daur, 2016; Atis et al., 2019) emphasized that hay or silage made by wizened grass is not a good option to feed livestock due to the lower quality. On the other side, some researchers emphasized that if managed well (plant age, cutting height, etc.) fresh or ensilaged GKG would almost meet the nutritional needs of cattle (NRC, 1978; Geren, 2014b; Geren and Kavut, 2015). There is limited information available regarding the cutting frequency or interval on the effect of metabolisable energy or cell wall component of GKG grown under Mediterranean climatic condition. Average NDF and ADF concentrations of GKG grown at different plant density in Mediterranean climate were reported to be 54.0 and $45.3 \%$ when cut once during growing season at $15 \mathrm{~cm}$ stubble height in Izmir, Turkey, respectively (Geren and Kavut, 2015). Kukkonen (2009) stated that young GKG first harvested at a height of 90 to $120 \mathrm{~cm}$ tall had a CP level of $19.5 \%$ of DM, with $56 \%$ NDF and $34 \%$ ADF in Illinois, USA. These figures are comparable to some legumes forage crops. Nevertheless, later, harvest of third growth the crop at a height of 120 to $220 \mathrm{~cm}$ on November had CP of $10.5 \%, 66 \% \mathrm{NDF}$ and $37 \%$ ADF. Shen et al. (2012) reported that cell wall component of king grass silage affected by different harvest time and wilting process with mean of $60 \%$ NDF and $30 \%$ ADF.

\section{CONCLUSION}

It should be emphasized that giant king grass, a new introduction to the Mediterranean coastal part of Turkey, is a promising perennial forage crop material with an high level of adaptability and forage yield and quality pecularities. The results of the present study indicate the potential of giant king grass to produce forage for silage in Turkey to satisfy the increasing need for roughage.

The results of the study testing the effect of six cutting frequency (30-, 60-, 90-, 120-, 150 and 180- day intervals) on the crop showed that based on dry matter, metabolisable energy or cell wall component, using 60- day intervals should be recommended in the regions with Mediterraneantype climates and in similar agro-ecologies of the country or other countries as well. Future experiments on giant king grass crop should be conducted at different locations with various agronomical treatments and especially cutting intervals (40-, 50-, 60- or 70- day) to be sure that results are relatively consistent over time. Additional research activities with rumen digestibility are also needed.

\section{ACKNOWLEDGEMENTS}

Research study (1150083) funded by The Scientific and Technological Research Council of Turkey (TUBITAK). Assistance in conducting the study was also received from Department of Field Crops and Animal Nutrition \& Feed Science, Faculty of Agriculture, Ege University, Turkey.

\section{LITERATURE CITED}

Alcicek, A. and K. Ozkan. 1996. Zur quantitativen Bestimmung von Milch-, Essig- und Buttersäuren in Silage mit Hilfe eines Destillationsverfahren. The Journal of Ege University, Faculty of Agriculture 33(2-3): 191-198 (in Turkish).

AOAC. 1991. Official methods of analysis. $15^{\text {th }}$ Edition, Association of Official Analytical Chemists, Washington DC.

Atis, I., N. Celiktas, E. Can and S. Yilmaz. 2019. The effects of cutting intervals and seeding rates on forage yield and quality of alfalfa. Turkish Journal of Field Crops 24(1): 1220.

Bazzaz, F.A., N.R. Chiariello, P.D. Coley and L.F. Pitelka. 1987. Allocating resources to reproduction and defence. Bioscience 37: 58-67.

Bernardino, F.S., R. Garcia, F.C. Rocha, A.L.de Souza and O.G. Pereira. 2005. Production and characteristics of effluent and bromatological composition of elephantgrass with different levels of coffee hulls addition. Revista Brasileira de Zootecnia. 34(6): 2185-2191.

Campos, F.P., D.P.D. Lanna, M.L.V. Bose, C. Boin and P. Sarmento. 2002. Elephantgrass (Pennisetum purpureum) degradability at different maturity stages evaluated by the in vitro/gas technique, Scientia Agricola 59(2): 217-225.

Carpici, E.B., N. Celik and G. Bayram. 2010. Yield and quality of forage maize as influenced by plant density and nitrogen rate. Turkish Journal of Field Crops 15(2): 128-132.

Carvalho, C.A.B., J.B.O.X. Menezes and A.C. Cóser. 2000. Effect of fertilization and cutting interval on production and nutritive value of elephantgrass. Ciênc. agrotec. Lavras. 24(1): 233-241.

Charmley, E. 2001. Towards improved silage quality - A review. Can. J. Anim. Sci. 81: 157-168.

Chong-jian, M., L. Fa-guang, C. Jing-chao and H. Jun-mei. 2011. Correlation analysis between yield and morphological traits of hybrid giant napier of different growth years. Pratacultural Science 28(8): 1473-1478.

Comberg, G. 1974. Gärfutter: Betriebswirtschaft, Erzeugung, Verfütterung, Verlag Eugen Ulmer Stuttgart, Gerokstraße 19, Printed in Germany, ISBN:3-8001-4321-6, 260s.

Daur, I. 2016. Feed value of blue panic (Panicum antidotale retz.) grass at different growth stages and under varying levels of humic acid in saline condition, Turkish Journal of Field Crops 21(2): 210-217.

Ferrari Junior, E., V.T. Paulino, R.A. Possenti and T.L. Lucenas. 2009. Additives in silage of paraisograss (Pennisetum hybridum cv. Paraiso). Arch. Zootec. 58(222): 185-194.

Geren, H., 2014a, Dry matter yield and silage quality of some winter cereals harvested at different stages under Mediterranean climate conditions, Turkish Journal of Field Crops, 19(2): 206-211.

Geren, H. 2014b. An investigation on some quality characteristics of ensilaged giant kinggrass (Pennisetum hybridum) with different levels of leguminous forages. The Journal of Ege University, Faculty of Agriculture 51(2): 209-217 (in Turkish).

Geren, H., R. Avcioglu, Y.T. Kavut, K. Tan and S. Sargin. 2014. An investigation on comparison of some annual warm season grasses with warm season perennial grasses in terms of ensilagable yield, forage quality and bio-ethanol yield under 
Mediterranean climate. The Journal of Ege University, Faculty of Agriculture 51(3): 243-251 (in Turkish).

Geren, H. and Y.T. Kavut. 2015. Effect of different plant densities on the yield and some silage quality characteristics of giant king grass (Pennisetum hybridum) under Mediterranean climatic conditions. Turkish Journal of Field Crops 20(1):8591.

Goering, H.K. and P.J. VanSoest. 1970. Forage Fiber Analysis (apparatus, reagents, prosedures and some applications) USDA Agricultural Handbook No. 379.

Hanna, W.W., T.P. Gaines, B. Gonzales and W.G. Monson. 1984. Effects of ploid on yield and quality of pearl millet $x$ Napier grass hybrids. Agron. J. 76:669-971.

Johnson, H.E., R.J. Merry, D.R. Davies, D.B. Kell, M.K. Theodorou and G.W. Griffith. 2005. Vacuum packing: a model system for laboratory-scale silage fermentations. Journal of Applied Microbiology 98: 106-113.

Kukkonen, C. 2009. Giant king grass, an energy crop for cellulosic biofuels \& electric power plants, Viaspace Inc. Irvine, California USA

Lounglawan, P., W. Lounglawan and W. Suksombat. 2014. Effect of cutting interval and cutting height on yield and chemical composition of King Napier grass (Pennisetum purpureum $x$ Pennisetum americanum). APCBEE Procedia. 8: 27-31.

Magalhães, J.A., E.A. Lopes, B.H.N. Rodrigues, N.L. Costa, N.N. Barros and D.A. Mattei. 2006. Influence of the nitrogen fertilization and of the cut age on the forage yield of the elephant grass. Revista Ciência Agronômica 37(1): 91-96.

Mbuthia, E.W. 2003. Effect of inclusion of protein-rich forages on quality of Napier grass silage. University of Nairobi, Faculty of Veterinary Medicine, Ph.D. Thesis, 149p.

Mohammad, N., N.M. Butt and L.A. Qamar. 1988. Effect of nitrogen fertilization and harvest intervals on the yield and nutritional value of Napier grass, Pakistan J. Agric. Res., 9(4):478-482.

Mushtaque, M., M. Ishaque and M.A.A.H.A. Bukhsh. 2010. Growth and herbage yield of Setaria sphacelata grass in response to varying clipping stages. The J. Anim. Pl. Sci. 20(4):261-265.

Nazli, RI., V. Tansi, H.H. Ozturk and A. Kusvuran. 2018. Miscanthus, switchgrass, giant reed, and bulbous canary grass as potential bioenergy crops in a semi-arid Mediterranean environment. Industrial Crops \& Products 125: 9-23.

NRC. 1978. Nutrient requirements of domestic animals. Nutrient requirements of dairy cattle. 5th edition. National Academy of Sciences, Washington, D.C.

Rengsirikul, K., Y. Ishii, K. Kangvansaichol, P. Pripanapong, P. Sripichitt, V. Punsuvon, P. Vaithanomsat, G. Nakamanee and S. Tudsri. 2011. Effects of inter-cutting interval on biomass yield, growth components and chemical composition of napiergrass (Pennisetum purpureum Schumach) cultivars as bioenergy crops in Thailand. Japanese Society of Grassland Science. Grassland Science 57: 135-141.

Ruviaro, C., A.B. Lazzeri, H.A.S. Thomaz and Z.B. Oliveira. 2008. Effects of nitrogen fertilization management on irrigated Elephant grass cv. Paraíso productivity. Irriga, Botucatu 13(1): 26-35.

SAS Institute. 1998. INC SAS/STAT user's guide release 7.0, Cary, NC, USA.

Shen, C., X. Shang, X. Chen, Z. Dong and J. Zhang. 2012. Growth, chemical components and ensiling characteristics of king grass at different cuttings. African Journal of Biotechnology 11(64):12749-12755.

Singh, B.P., H.P. Singh and E. Obeng. 2013. Biofuel Crops: Production, Physiology and Genetics; $13^{\text {th }}$ section: Elephant grass, (ed. B.P. Singh), CAB International, p: 271-291.

Stell, R.G.D., J.A. Torrie and D.A .Dickey. 1997. Principles and Procedures of Statistics. A. Biometrical Approach $3^{\text {rd }}$ Edi. Mc Graw Hill Book. INC. NY.

Tegami Neto, Â. and S. Mello. 2007. Avaliação da produtividade e qualidade do capim paraíso (Pennisetum hybridum), em função de diferentes doses de nitrogênio em cobertura e freqüência de corte. Nucleus, 4(1-2): 9-12.

Tessema, Z.K., J. Mihret and M. Solomon. 2010. Effect of defoliation frequency and cutting height on growth, dry-matter yield and nutritive value of Napier grass (Pennisetum purpureum (L.) Schumach). Grass and Forage Science 65: 421-430.

TSE, 2004. Determination of Metabolisable Energy in Forages (Chemical method), Turkish Standards Institution (TSE), Standard No:9610, Ankara (in Turkish).

Wadi, A., Y. Ishii and S. Idota. 2004. Effects of cutting interval and cutting height on dry matter yield and overwintering ability at the established year in Pennisetum species. Plant Prod. Sci. 7(1): 88-96.

Wijitphan, S., P. Lorwilai and C. Arkaseang. 2009. Effects of plant spacing on yields and nutritive values of napier grass (Pennisetum purpureum Schum.) under intensive management of nitrogen fertilizer and irrigation. Pakistan Journal of Nutrition. 8(8): 1240-1243.

Woodard, K.R., G.M. Prine and D.B. Bates. 1991. Silage characteristics of elephant grass as affected by harvest frequency and genotype. Agronomy Journal 83(3): 547-551.

Zewdu, T. 2008. Effect of plant density on morphological characteristics, yield and chemical composition of napier grass (Pennisetum purpureum (L.) Schumach). East African Journal of Science, 2(1): 55-61. 